\title{
SINTESIS OKSIDA GRAFENA DARI ARANG TEMPURUNG KELAPA UNTUK APLIKASI ANTIBAKTERI DAN ANTIOKSIDAN
}

\author{
AHMAD SJAHRIZA $^{1,2^{*}}$ DAN SURYA HERLAMBANG ${ }^{1}$ \\ ${ }^{1}$ Departemen Kimia, Fakultas Matematika dan Ilmu pengetahuan Alam, Institut Pertanian Bogor, Dramaga, \\ Bogor, Jawa Barat, Indonesia \\ ${ }^{2}$ Laboratorium Kimia Terpadu, Institut Pertanian Bogor, Bogor, Jawa Barat, Indonesia \\ *alamat email korespondensi: ahmadsj@ apps.ipb.ac.id
}

\begin{tabular}{|c|c|}
\hline Informasi Artikel & Abstrak/Abstract \\
\hline $\begin{array}{l}\text { Riwayat Naskah: } \\
\text { Diterima pada } 23 \\
\text { Juli } 2021 \\
\text { Diterima setelah } \\
\text { direvisi pada } 23 \\
\text { Desember } 2021 \\
\text { Diterbitkan pada } 31 \\
\text { Desember } 2021 \\
\text { Kata Kunci: } \\
\text { antibakterli; } \\
\text { antioksidan; arang } \\
\text { tempurung kelapa; } \\
\text { oksida grafena. }\end{array}$ & $\begin{array}{l}\text { Oksida grafena adalah turunan dari grafena yang mudah disintesis dan aplikasi yang sangat } \\
\text { luas. Penelitian ini bertujuan menyintesis_oksida grafena dari arang tempurung kelapa yang } \\
\text { memiliki karakter partikel nano karbon sebagai antibakteri dan antioksidan. Oksida grafena } \\
\text { dari arang tersebut berhasil disintesis dengan rendemen } 1,85 \% \text { b/b menggunakan modifikasi } \\
\text { metode Hummers dengan ukuran rataan partikel } 33,7 \mathrm{~nm} \text {. Gugus fungsi beroksigen pada } \\
\text { spektrum inframerah pada bilangan gelombang } 2933 \mathrm{~cm}^{-1} \text { dan } 1615 \mathrm{~cm}^{-1} \text { menandakan oksida } \\
\text { grafena berhasil terbentuk. Puncak difraksi sinar X } 23,5^{\circ} \text { dan kristalinitas sebesar } 6,85 \% \text {. } \\
\text { Derajat kristalinitas yang rendah menunjukan bahwa oksida grafena memiliki fasa amorf. } \\
\text { Aktivitas antioksidan ditentukan berdasarkan kemampuannya mereduksi besi(III) dan hasil } \\
\text { sintesis memperlihatkan aktivitas antioksidan sebesar } 50 \% \text { dibanding standar. Hasil pengujian } \\
\text { antibakteri ditandai dengan terbentuknya zona bening terhadap bakteri Escherichia coli dan } \\
\text { Staphylococcus aureus sehingga oksida grafena memiliki aktivitas antibakteri namun } \\
\text { tergolong lemah. }\end{array}$ \\
\hline $\begin{array}{l}\text { Keywords: } \\
\text { antibacterial; } \\
\text { antioxidant; coconut } \\
\text { shell charcoal; } \\
\text { graphene oxide. }\end{array}$ & $\begin{array}{l}\text { Graphene oxide is the most easily synthesized graphene derivative and has wide applications. } \\
\text { This study aims to synthesize graphene oxide from coconut shell charcoal which has carbon } \\
\text { nanoparticle characteristics as antibacterial and antioxidant. Graphene oxide from charcoal } \\
\text { was successfully synthesized with a yield of } 1.85 \% \text { w/w using the modified Hummers method } \\
\text { with an average particle size of } 33.7 \mathrm{~nm} \text {. The oxygenated functional group in the infrared } \\
\text { spectrum at wavenumber } 2933 \mathrm{~cm}^{-1} \text { and } 1615 \mathrm{~cm}^{-1} \text { indicates that graphene oxide has been } \\
\text { successfully formed. The peak of X-ray diffraction was } 23.5^{\circ} \text { and crystallinity was } 6.85 \% \text {. The } \\
\text { low degree of crystallinity indicates that graphene oxide has an amorphous phase. Antioxidant } \\
\text { activity was determined based on its ability to reduce iron(III) and the results of the synthesis } \\
\text { showed antioxidant activity } 50 \% \text { lower than standard. The results of the antibacterial test } \\
\text { were indicated by the formation of a clear zone against Escherichia coli and Staphylococcus } \\
\text { aureus bacteria while the result showed graphene oxide had an antibacterial activity with low } \\
\text { activity. }\end{array}$ \\
\hline
\end{tabular}

\section{PENDAHULUAN}

Grafena adalah nanomaterial berbentuk dua dimensi monoatomik yang terdiri dari satu lapis grafit. Grafena dianggap sebagai material tertipis di dunia, berupa selembar atom karbon ikatan $s p^{2}$ dalam kisi dua dimensi heksagonal. Meskipun sangat tipis kekuatan grafena melebihi baja, hal ini disebabkan oleh ikatan kovalen antar karbonnya yang kuat sehingga menyebabkan grafena sulit untuk diregangkan [1].

Oksida grafena (Gambar 1) merupakan turunan grafena yang paling mudah disintesis dan memiliki gugus fungsional oksigen yang terpasang pada bidang dasar dan tepi lembarannya. Sifat-sifat menarik dari oksida grafena berasal dari struktur kimianya yang unik yang terdiri atas domain karbon $s p^{2}$ kecil yang dikelilingi oleh domain karbon $s p^{3}$ dan oksigen yang mengandung gugus fungsi hidrofilik [2].

Oksida grafena umum berbahan dasar grafit, namun pada penelitian ini oksida grafena akan disintesis menggunakan biomasa [3] yakni arang tempurung kelapa. Pemilihan arang tempurung kelapa karena memiliki sumber atom karbon yang melimpah, aman, berkelanjutan dan termasuk pada proses dengan pendekatan kimia hijau [4].

Kelanjutan dari penelitian sebelumnya yang mempelajari sifat mekanik dan penghalang dari partikel karbon nano [5] adalah mengamati karakteristik dasar dari partikel nano yang meliputi distribusi ukuran partikel, gugus fungsi dan ciri sudut hamburan oksida grafena. Selanjutnya karbon nano dalam bentuk oksida grafena ini akan diuji terhadap aktivitas sebagai antioksidan dan 
antibakteri yang selama ini menggunakan grafena atau oksida grafena berbahan dasar grafit
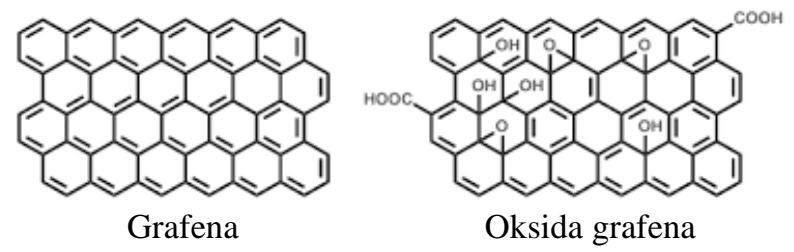

Gambar 1. Struktur garfena dan oksida grafena [6].

\section{EKSPERIMEN}

Penelitian ini dimulai dengan menyintesis oksida grafena dari arang tempurung kelapa. kemudian hasil sintesis berupa oksida grafena dikarakterisasi sebagai partikel karbon nano yang meliputi distribusi dan ukuran partikel nano, gugus fungsi dan analisa sudut hamburan grafena. Tahap terakhir oksida grafena di uji aktivitas antioksidan menggunakan metoda Ferric Reducing Antioxidant Power (FRAP) dan uji aktivitas antibakteri melalui metoda difusi sumur.

\section{Material}

Material yang digunakan antara lain tempurung kelapa, $\mathrm{H}_{2} \mathrm{SO}_{4} \quad 98 \%$ (MERCK, Darmstadt, Jerman), $\mathrm{KMnO}_{4}$ (MERCK, Darmstadt, Jerman), $\mathrm{H}_{2} \mathrm{O}_{2} 30 \%$ (MERCK, Darmstadt, Jerman), $\mathrm{HCl}$ (MERCK, Darmstadt, Jerman), $\mathrm{KH}_{2} \mathrm{PO}_{4}$ (MERCK, Darmstadt, Jerman), $\mathrm{K}_{2} \mathrm{HPO}_{4}$ (Kanto Chemical Co. INC, Tokyo, Jepang), asam trikloroasetat (MERCK, Darmstadt, Jerman), $\mathrm{FeCl}_{3}$ (MERCK, Darmstadt, Jerman), $\mathrm{K}_{3} \mathrm{Fe}(\mathrm{CN})_{6}$ (Sigma Aldrich, Steinheim, Jerman), akuades, akuabides, asam askorbat (Sigma Aldrich, Steinheim, Jerman), air laut, dan larva udang Artemia salina Leach.

\section{Instrumentasi}

Instrumentasi yang Spektrofotometer UVVis shimadzu double beam, Fourier Transform Infrared (FTIR) Parkin Elmer Spectra One, X-Ray Diffractometer (XRD)-7000 Shimadzu, Particle Size Analizer (PSA), aerator, Sonikator, penangas air, termometer, dan sentrifuge.

\section{Prosedur}

\section{Sintesis Oksida Grafena dari Arang Tempurung} Kelapa

Oksida grefena disintesis menggunakan modifikasi metode Hummers [7]. Serbuk arang tempurung kelapa sebanyak $3 \mathrm{~g}$ ditambahkan 70 $\mathrm{mL} \mathrm{H}_{2} \mathrm{SO}_{4}$ pekat yang sudah berada di dalam gelas kimia. Gelas kimia tersebut disimpan pada ice bath, kemudian ditambahkan $\mathrm{KMnO}_{4}$ sebanyak $9 \mathrm{~g}$ sedikit demi sedikit agar suhu campuran tidak melebihi $20^{\circ} \mathrm{C}$, Selanjutnya, ditambahkan $150 \mathrm{~mL}$ air. Suspensi kemudian diaduk selama dua jam pada suhu $35^{\circ} \mathrm{C}$. Suspensi didiamkan selama 5 hari untuk proses oksidasi. Setelah proses oksidasi selesai, kemudian ditambahkan $250 \mathrm{~mL}$ air dan 7,5 $\mathrm{mL} \mathrm{H}_{2} \mathrm{O}_{2}$. Campuran kemudian dicuci dengan larutan $\mathrm{HCl}$ sebanyak $500 \mathrm{~mL}(1: 10 \sim \mathrm{HCl}:$ air $)$ agar ion logam dapat dihilangkan. Pada tahap ini akan dihasilkan endapan yang kemudian dikeringkan pada suhu $60^{\circ} \mathrm{C}$ selama 6,5 jam hingga kering kemudian dilakukan pemurnian dengan cara mencuci suspensi dengan air dalam jumlah besar.

Endapan yang telah dikumpulkan kemudian didispersikan ke dalam $300 \mathrm{~mL}$ air kemudian oksida grafena dikelupas secara mekanik dengan sonikator selama 20 menit, kemudian disentrifugasi pada 4000 rpm selama 30 menit untuk memisahkan grafit oksida yang tidak terkelupas. Setelah proses sentrifugasi, oksida grafena akan berada di dasar wadah. Selanjutnya oksida grafena dikeringkan pada temperatur $60^{\circ} \mathrm{C}$. Serpihan oksida grafena akan diperoleh dengan cara mengerik padatan oksida grafena dari cawan.

\section{Karakterisasi Oksida Grafena}

Karakterisasi oksida grafena menggunakan alat yaitu Spektrofotometer UV-Vis, Fourier Transform Infared (FTIR), Particle Size Analyzer (PSA) dan X-Ray Diffraction (XRD). Pengukuran sampel dengan Spektrofotometer UV-Vis dilakukan dengan melarutkan sampel dengan akuades kemudian diukur pada rentang panjang gelombang 200-400 nm. Pengukuran sampel dengan FTIR dilakukan dengan sampel dikeringkan pada oven suhu $60^{\circ} \mathrm{C}$ selama 3-5 jam dan disiapkan $\mathrm{KBr}$ yang sudah dikeringkan. Kemudian sampel diukur pada alat FTIR dengan rentang bilangan gelombang 450-4000 $\mathrm{cm}^{-1}$. Pengukuran sampel dengan PSA dilakukan dengan melarutkan sampel dalam akuabides. Pengukuran sampel dengan XRD dilakukan dengan sampel yang sudah dikeringkan dan diukur pada sudut $2 \theta$ dalam rentang sudut $5^{\circ}-75^{\circ}$.

\section{Uji Aktivitas Antibakteri}

Uji aktivitas antibanteri dilakukan dengan menyiapkan media bakteri, yaitu Tryptic Soy Agar (TSA) dan Tryptic Soy Broth (TSB). Selanjutnya media TSA dan TSB dilakukan sterilisasi dengan autoklaf selama 1 jam. Media TSB yang sudah dibuat lalu ditambahkan masing-masing inokulum bakteri Staphylococcus aureus dan Escherichia 
coli. Kemudian dilakukan inkubasi selama 24 jam. Setelah inkubasi, media TSB berubah menjadi jenuh dan sebanyak $1 \mathrm{~mL}$ media TSB dituang di atas media TSA pada cawan petri. Selanjutnya media TSB diratakan perlahan diseluruh bagian atas media TSA. Kemudian cakram kertas ditaruh di atas media TSA menggunakan pinset. Selanjutnya oksida grafena dilarutkan dalam akuabides dengan konsentrasi sebesar $1000 \mu \mathrm{g} / \mathrm{mL}$ dan diteteskan di atas cakram kertas. Kemudian cawan petri ditutup untuk dilakukan inkubasi selama 24 jam dalam inkubator pada suhu $35^{\circ} \mathrm{C}$. Setelah inkubasi, ada atau tidaknya zona bening yang terbentuk di sekitar sampel diamati dan diameter zona bening diukur.

\section{Uji Aktivitas Antioksidan}

Larutan induk asam askorbat dengan konsentrasi $1000 \mu \mathrm{g} / \mathrm{ml}$ dibuat dari $10 \mathrm{mg}$ asam askorbat yang dilarutkan dengan akuades dalam labu takar $10 \mathrm{ml}$ hingga tanda batas. Larutan tersebut kemudian dengan konsentrasi 8, 12, 16, 20, 24, dan $28 \mu \mathrm{g} / \mathrm{mL}$. Sedangkan untuk sampel, sebanyak $10 \mathrm{mg}$ oksida grafena didispersikan dalam $10 \mathrm{~mL}$ air untuk mendapatkan konsentrasi $1000 \mu \mathrm{g} / \mathrm{mL}$. Larutan kemudian dibuat dengan konsentrasi 10, 20, 30, 40, dan $50 \mu \mathrm{g} / \mathrm{mL}$.

Larutan blanko disiapkan dengan menggunakan buffer fosfat $\mathrm{pH} 6,6$ sebanyak $2 \mathrm{~mL}$ dalam vial, kemudian ditambah $2 \mathrm{~mL}$ larutan $\mathrm{K}_{3} \mathrm{Fe}(\mathrm{CN})_{6} 1 \% \mathrm{~b} / \mathrm{v}$, selanjutnya diinkubasi dalam penangas air selama 20 menit pada suhu $50^{\circ} \mathrm{C}$. Kemudian larutan ditambahkan asam trikloroasetat $10 \%$ sebanyak $2 \mathrm{~mL}$ selanjutnya sebanyak $2 \mathrm{~mL}$ campuran tersebut dimasukan ke dalam vial kemudian ditambahkan $2 \mathrm{~mL}$ aquades dan $0,4 \mathrm{~mL}$ $\mathrm{FeCl}_{3} \quad 0,1 \%$ b/v kemudian larutan diukur serapannya pada panjang gelombang $700 \mathrm{~nm}$.

Larutan uji disiapkan dengan cara larutan buffer fosfat $\mathrm{pH}$ 6,6 sebanyak $2 \mathrm{~mL}, 2 \mathrm{~mL}$ larutan $\mathrm{K}_{3} \mathrm{Fe}(\mathrm{CN})_{6} \quad 1 \% \quad \mathrm{~b} / \mathrm{v}$, kemudian larutan asam askorbat serta oksida grafena berbagai konsentrasi masing-masing dimasukan ke dalam vial kemudian diinkubasi dalam penangas air selama 20 menit pada suhu $50^{\circ} \mathrm{C}$. Setelah diinkubasi dan dibiarkan hingga dingin kemudian larutan ditambahkan TCA sebanyak $2 \mathrm{~mL}$, selanjutnya sebanyak $2 \mathrm{~mL}$ campuran tersebut dimasukan ke dalam vial kemudian ditambahkan $2 \mathrm{~mL}$ aquades dan $0,4 \mathrm{~mL}$ $\mathrm{FeCl}_{3}$. Larutan tersebut diukur serapannya pada panjang gelombang $700 \mathrm{~nm}$. Aktivitas antioksidan oksida grafena dinyatakan berdaasarkan besarnya nilai absorbans yang sebanding dengan besarnya kemampuan reduksi dari senyawa antioksidan tersebut [8].

\section{HASIL DAN PEMBAHASAN}

\section{Sintesis Oksida Grafena}

Sintesis dilakukan menggunakan modifikasi metode Hummers yaitu dengan menghilangkan penggunaan $\mathrm{NaNO}_{3}$. Penghilangan ini untuk menghindari gas $\mathrm{NO}_{2}$ dan $\mathrm{N}_{2} \mathrm{O}_{4}$ yang beracun selama proses oksidasi. Modifikasi ini tidak akan mempengaruhi dispersibilitas, struktur, ketebalan dan dimensi oksida grafena jika dibandingkan dengan metode tanpa modifikasi [9]

Proses interkalasi dan oksidasi dilakukan secara bersamaan. $\mathrm{KMnO}_{4}$ merupakan oksidator kuat terutama dalam suasana asam, proses interkalasi meningkatkan efektivitas masuknya $\mathrm{KMnO}_{4}$ ke dalam lapisan grafena untuk mengoksidasi arang [10]. Proses oksidasi ini menyebabkan grafit oksida mengalami penurunan kekuatan ikatan Van der Waals antar lapisan sehingga akan memudahkan pengelupasan oksida grafena. Proses oksidasi dihentikan dengan penambahan $\mathrm{H}_{2} \mathrm{O}_{2}$, yang selanjutnya dilakukan pengelupasan lapisan okasida grafena dengan bantuan glombang ultrasonik.

Oksida grafena yang berhasil disintesis memiliki berwujud hitam (Gambar 2). Hasil sintesis oksida grafena dari $3 \mathrm{~g}$ serbuk arang sebanyak $30 \mathrm{mg}$ (rendemen $1,85 \% \mathrm{~b} / \mathrm{b}$ ). Untuk melihat keberhasilan sintesis oksida grafena dilakukan dengan metode spektrofotometri UVVis, Infra merah, kristalinitas menggunakan XRD, dan ukuran partikelnya menggunakan PSA.

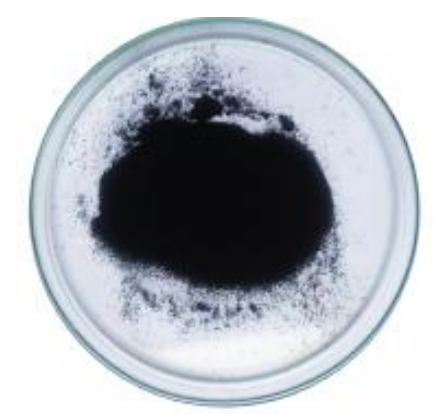

Gambar 2. Oksida Grafena dari arang tempurung kelapa.

\section{Karakterisasi Hasil Sintesis Oksida Grafena dari Tempurung Kelapa}

Analisis ukuran partikel menggunakan PSA terdapat 2 puncak grafik ukuran, yaitu sebesar $257,9 \mathrm{~nm}$ dengan persen distribusi molekul sebesar $0,1 \%$ dan Oksida grafena ukuran 33,79 $\mathrm{nm}$ dengan 
distribusi molekul sebesar 99,9\% (Gambar 3). ukuran partikel didominasi dengan ukuran partikel $33,79 \mathrm{~nm}$ yang menandakan hasil sintesis oksida grafena termasuk nanopartikel yang dapat digunakan sebagai nanomaterial [11], serta ukuran nano akan menaikan efektivitas dari aktivitas sebagai antioksidan dan antibakteri.

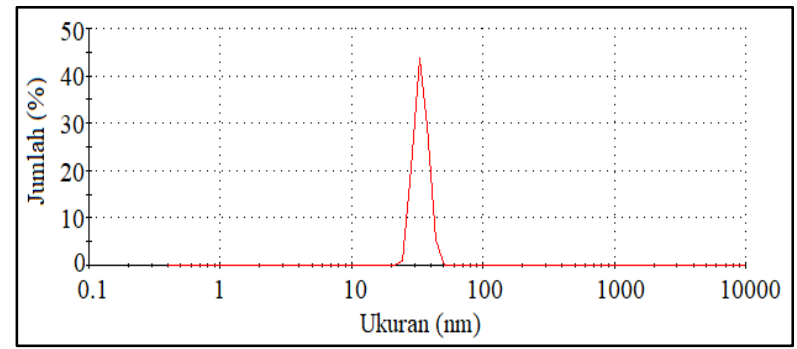

Gambar 3. Distribusi partikel oksida grafena.

Spektrofotometer UV-Vis digunakan untuk melihat oksida grafena yang terbentuk. Oksida grafena memiliki gugus fungsi Hidroksil (-OH) dan karbonil $(-\mathrm{C}=\mathrm{O})$ yang akan menghasilkan serapan pada spektrofotometri UV-Vis (Gambar 4). Menurut Mangadlao et al. (2015) [12] dan Pham, Viet Hung et al. [13] serapan oksida grafena terjadi pada $230 \mathrm{~nm}$. Hasil pemayaran 200-400 nm menunjukan serapan di $234 \mathrm{~nm}$ sedangkan pada bahan baku arang tempurung kelapa tidak terdapat puncak serapan.

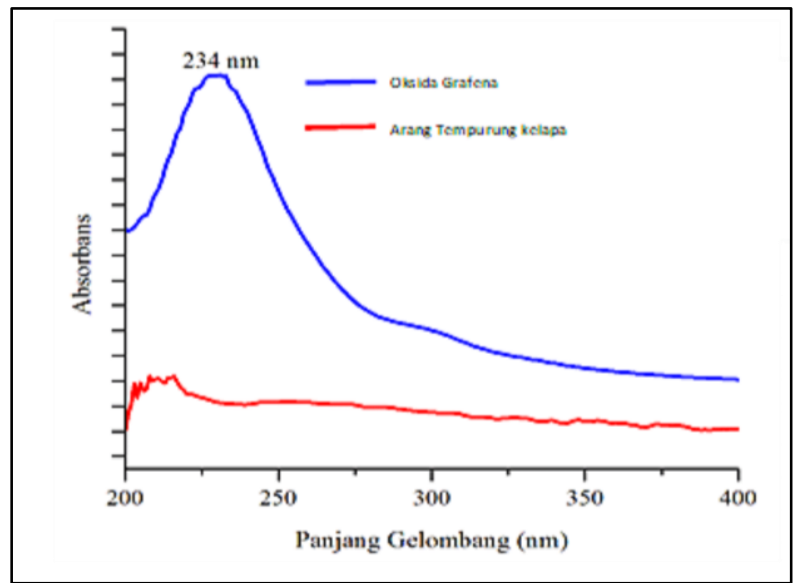

Gambar 4. Spektrum UV-Vis puncak serapan senyawa oksida grafena dan arang tempurung kelapa.

Spektrofotometer FTIR digunakan untuk melihat gugus fungsional yang ada pada oksida grafena. Spektrum inframerah dari arang tempurung kelapa menunjukan adanya puncak serapan untuk ikatan -OH pada bilangan gelombang $2933 \mathrm{~cm}^{-1}$ sedangkan pada bilangan gelombang $1615 \mathrm{~cm}^{-1}$ menunjukan adanya ikatan $\mathrm{C}=\mathrm{C}$ dari cincin aromatik. Puncak pada bilangan gelombang $1097 \mathrm{~cm}^{-1}$ merupakan ikatan $\mathrm{C}-\mathrm{O}$ dan bilangan gelombang $618 \mathrm{~cm}^{-1}$ menunjukan adanya ikatan $\mathrm{C}-\mathrm{H}$. Spektrum yang muncul sesuai dengan spektrum inframerah arang tempurung kelapa yang telah dilaporkan oleh Supriyanto et al. [14] sehingga grafit dari arang tempurung kelapa pada penelitian ini dapat digunakan sebagai material awal untuk sintesis oksida grafena.

Gugus-gugus fungsional oksigen pada struktur oksida grafena dari arang tempurung kelapa terlihat muncul pada puncak serapan sekitar bilangan gelombang $3420 \mathrm{~cm}^{-1}$ yang menunjukkan adanya ikatan $-\mathrm{OH}$, spektrum pada bilangan gelombang $1743 \mathrm{~cm}^{-1}$ mengarah kepada ikatan $\mathrm{C}=\mathrm{O}$, dan pada bilangan gelombang $1182 \mathrm{~cm}^{-1}$ merupakan spektrum ikatan $\mathrm{C}-\mathrm{O}$ (Gambar 5). Hasil penelitian ini sesuai dengan spektrum yang muncul pada oksida grafena dari grafit komersial Guo et al. (2013) [15] . Sintesis oksida grafena dari arang tempurung kelapa berhasil terbentuk, karena spektrum oksida grafena yang diperoleh pada penelitian ini sesuai dengan spektrum oksida grafena yang disintesis dari grafit komersial [16].

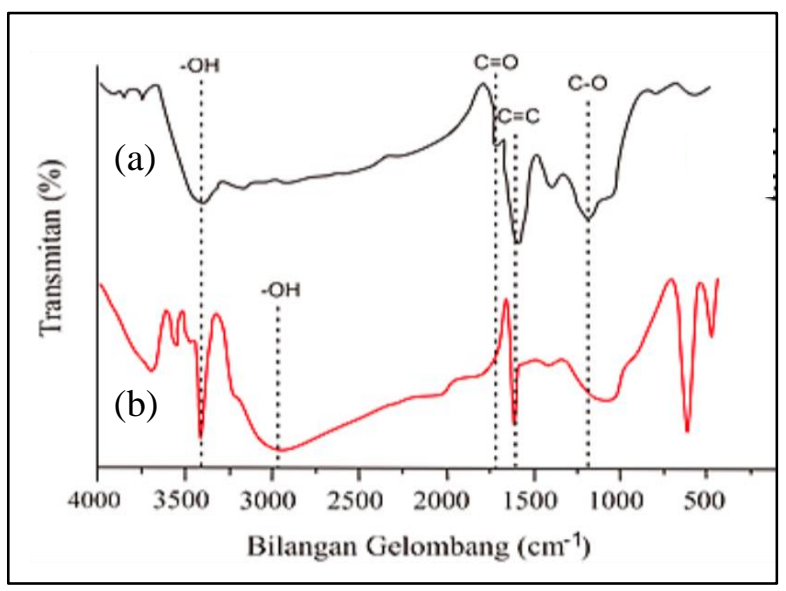

Gambar 5. Spektrum FTIR puncak serapan senyawa (a) oksida grafena dan (b) arang tempurung kelapa.

Pengukuran spektrum XRD puncak oksida grafena berbeda dengan arang tempurung kelapa yang khusus yang berasal tempurung kelapa bernilai sekitar 23,11 (Gambar 6) ditunjukkan dengan nilai berturut-turut $23,50^{\circ}$ dan $20,43^{\circ}$. Untuk oksida grafena yang berasal dari grafit memiliki sudut sekitar $10^{\circ}$ menurut Supriyanto et al. [14]. Dengan menghitung luas puncak spektrum XRD, dengan metode Full Witdh at Half Maximum (FWHM), Oksida grafena memiliki ukuran kristal lebih besar memiliki derajat kristalinitas yang lebih tinggi yaitu $15 \%$ sedangkan arang tempurung kelapa $10 \%$. Perbedaan derajat kristalinitas ini dipengaruhi oleh ukuran kristal, semakin besar ukuran kristal maka derajat kristalinitas akan semakin tinggi Derajat 
kristalinitas adalah perbandingan antara fase kristal dengan fasa amorf yang terdapat pada suatu material. Derajat kristalinitas dan ukuran kristal menunjukan bahwa oksida grafena memiliki fase amorf yang lebih dominan. Hal ini di sebabkan oleh material awal yang digunakan merupakannarang tempurung kelapa yang sangat amorf sehingga oksida grafena yang dihasilkan juga akan berbentuk amorf.

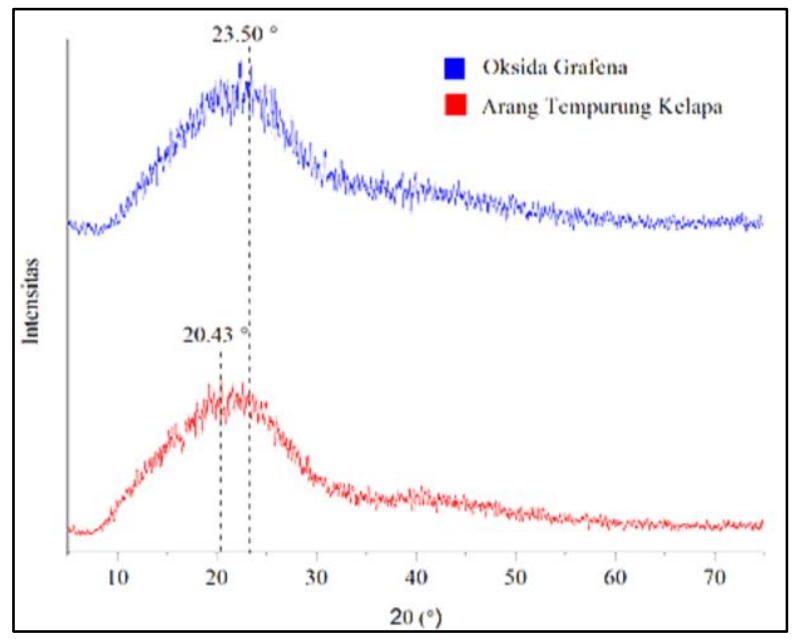

Gambar 6. Spektrum XRD puncak serapan senyawa oksida grafena dan arang kelapa.

\section{Aktivitas Antibakteri Oksida Grafena dari Arang Tempurung Kelapa}

Pengujian aktivitas antibakteri pada senyawa oksida grafena dilihat dari terbentuknya zona inhibitor (zona bening). Pertumbuhan bakteri yang terhambat ditandai dengan terbentuknya zona bening disekitar cakram kertas. Oksida grafena dengan konsentrasi $1000 \mu \mathrm{g} / \mathrm{mL}$ diuji aktifitas bakterinya. Menurut Ghanim et al. (2018) [16], oksida grafena dengan konsentrasi $1000 \mu \mathrm{g} / \mathrm{mL}$ pengujian aktivitas antibakteri menunjukkan terbentuknya zona bening. Oksida grafena yang diuji terhadap bakteri S.aureus menunjukkan zona bening sebesar $25 \mathrm{~mm}$. Oksida grafena yang diuji terhadap bakteri Escherichia coli menunjukkan zona bening sebesar $19 \mathrm{~mm}$. Berdasarkan hal tersebut, zona bening dalam penelitian oksida grafena dikatakan memiliki diameter yang lebih kecil daripada diameter zona bening dalam literatur. Zona bening dengan diameter yang kecil menunjukkan aktivitas antibakteri dikategorikan masih lemah. Diameter zona bening oksida grafena penelitian dan literatur menurut Ghanim et al. (2018) [16] terhadap Staphylococcus aureus dan Escherichia coli terlihat pada Tabel 1.
Hasil pengamatan menunjukkan bahwa pengujian dengan bakteri Staphylococcus aureus terbentuk zona bening dengan diameter $1,1 \mathrm{~cm}$ atau $11 \mathrm{~mm}$. Sedangkan pada bakteri Escherichia coli terbentuk zona bening dengan diameter $0,5 \mathrm{~cm}$ atau $5 \mathrm{~mm}$. Berikut hasil pengujian aktivitas antibakteri dapat dilihat pada Gambar 7 dan Gambar 8. Oksida grafena dapat menghambat pertumbuhan kedua bakteri yang diuji. Oksida grafena memiliki gugus $\mathrm{O}-\mathrm{H}$ pada bagian tepi lapisan yang dapat mengganggu kestabilan permeabilitas membran sel bakteri. Oksida grafena memiliki beberapa gugus fungsi pada permukaannya seperti hidroksil, karbonil, dan karboksilat yang membuat oksida grafena stabil dalam air [4].

Kelompok fungsional ini menyebabkan oksida grafena berinteraksi kuat dengan sekitarnya. Oksida grafena menunjukkan aktivitas antibakteri terhadap berbagai patogen melalui interaksi fisik dan kimia. Interaksi fisik terkait kerusakan fisik dengan induksi oleh kontak langsung dari ujung tajam oksida grafena dengan membran bakteri. Interaksi secara kimia terkait dengan stres oksidatif yang dihasilkan oleh transfer muatan dan spesies oksigen reaktif (ROS). Kerusakan membran oleh ujung oksida grafena yang tajam (Gambar 9) dapat menembus membran sel dan secara fisik mengganggu integritasnya Ghanim et al. (2018) [16]. Berikut mekanisme aktifitas antibakteri oksida grafena secara interaksi fisik. Gambar 9 memperlihatkan mekanisme aktivitas antibakteri oksida grafena terhadap bakteri [17] .Selain itu, stres oksidatif diinduksi oleh oksida grafena berkontribusi terhadap kerusakan membran sel bakteri. Stres oksidatif adalah penyebab dari sifat toksisitas karena bakteri tidak dapat lagi berkembang biak setelah deaktivasi protein dan lipidnya melalui mekanisme ROS yang diproduksi oleh oksida grafena [18]. Namun, ukuran oksida grafena tidak kondusif untuk penyerapan seluler. Oleh karena itu, ukuran oksida grafena dibuat berukuran nano untuk meningkatkan aktivitas antibakteri [8].

Tabel 1. Diameter zona bening oksida grafena penelitian dan literatur.

\begin{tabular}{lcc}
\hline & \multicolumn{2}{c}{ Diameter zona bening (mm) } \\
\cline { 2 - 3 } Jenis bakteri & $\begin{array}{c}\text { Oksida } \\
\text { grafena } \\
\text { (penelitian) }\end{array}$ & $\begin{array}{c}\text { Oksida grafena } \\
\text { Ghinam } \text { et al. } \\
{[10]}\end{array}$ \\
\hline $\begin{array}{l}\text { Staphylococcus } \\
\text { aureus }\end{array}$ & 11 & 25 \\
\hline Escherichia coli & 5 & 19 \\
\hline
\end{tabular}




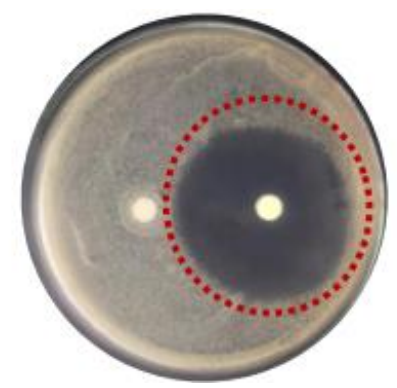

Gambar 7. Zona bening oksida grafena terhadap bakteri Staphylococcus aureus.

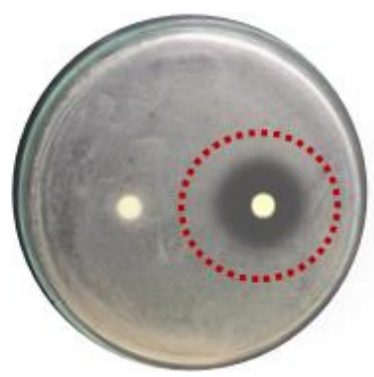

Gambar 8. Zona bening oksida grafena terhadap bakteri Escherichia coli.

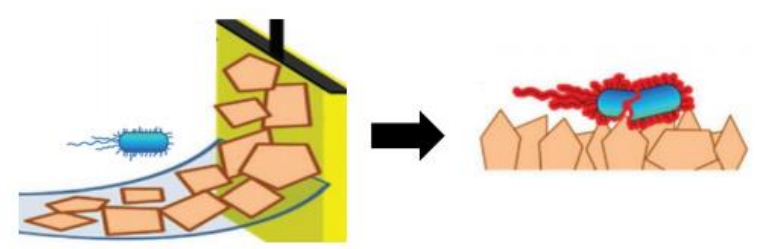

Gambar 9. Mekanisme aktivitas antibakteri oksida grafena terhadap bakteri [17].

\section{Aktivitas Antioksidan Oksida Grafena dari Arang Tempurung Kelapa}

Nanomaterial karbon mempunyai aktivitas antioksidan karena dapat menurunkan pembentukan Reactive oxygen species (ROS) dan juga dapat menangkap ROS, seperti yang dilaporkan oleh beberapa penelitian terhadap carbon nanotube (CNTs) dan carbon dot [19]. Perlindungan oksidasi oleh bahan-bahan karbon dapat melibatkan pembentukan adisi radikal pada situs-situs karbon $s p^{2}$, melalui transfer elektron, donor hidrogen dari kelompok-kelompok fungsional, atau melalui pembentukan kelat ion logam transisi dan penghambatan pembentukan radikal [20]. Oksida grafena merupakan suatu nanomaterial karbon yang diharapkan juga mempunyai kemampuan antioksidan.

Aktivitas antioksidan oksida grafena pada penelitian ini ditentukan dengan menggunakan metode Ferric Reducing Antioxidant Power (FRAP). Metode ini dapat menentukan kandungan antioksidan suatu bahan melalui kemampuan senyawa antioksidan untuk mereduksi ion $\mathrm{Fe}^{3+}$ menjadi $\mathrm{Fe}^{2+}$, kekuatan antioksidan suatu senyawa dianalogikan dengan kemampuan mereduksi dari senyawa tersebut. Metode ini senyawa antioksidan akan reduksi kalium ferrisianida $\left(\mathrm{K}_{3} \mathrm{Fe}(\mathrm{CN})_{6}\right)$ menjadi kalium ferrosianida $\left(\mathrm{K}_{4} \mathrm{Fe}(\mathrm{CN})_{6}\right)$.

Kemampuan sampel dalam mereduksi $\mathrm{Fe}^{3+}$ dapat terlihat dari adanya peningkatan absorbans yang berbanding lurus dengan meningkatnya konsentrasi. Aktivitas antioksidan asam askorbat sebagai kontrol positif menunjukan kemampuan mereduksi yang sangat baik (Gambar 10), terlihat pada peningkatan absorbans yang cukup tinggi pada konsentrasi $8 \mu \mathrm{g} / \mathrm{mL}$ jika dibandingkan dengan blanko (Tabel 2). Aktivitas antioksidan yang sangat baik ini disebabkan oleh adanya senyawa fenolik yang dapat mendonorkan elektron dengan sangat baik sehingga semakin banyak $\mathrm{Fe}^{3+}$ yang dapat direduksi. Oksida grafena juga memiliki aktivitas antioksidan karena mampu mereduksi $\mathrm{Fe}^{3+}$ dengan adanya peningkatan absorbans yang berbanding lurus pada peningkatan konsentrasi.Oksida grafena mempunyai kemampuan sebagai antioksidan karena mampu mereduksi $\mathrm{Fe}^{3+}$ (Tabel 3). Namun, berdasarkan nilai $\mathrm{R}^{2}$ oksida grafena yang lebih rendah menandakan kekuatannya untuk mereduksi masih belum sebaik asam askorbat (Gambar 11).

Tabel 2. Hubungan Konsentrasi Asam Askorbat dengan serapan pada Panjang gelombang $700 \mathrm{~nm}$.

\begin{tabular}{|c|c|c|}
\hline Sampel & $\begin{array}{c}\text { Konsentrasi } \\
(\mu \mathrm{g} / \mathrm{mL})\end{array}$ & Absorbans \\
\hline \multirow{5}{*}{ Asam askorbat } & 8 & 0.207 \\
\hline & 12 & 0.284 \\
\hline & 16 & 0.384 \\
\hline & 20 & 0.461 \\
\hline & 24 & 0.532 \\
\hline Blanko & - & 0.032 \\
\hline \multirow{10}{*}{ 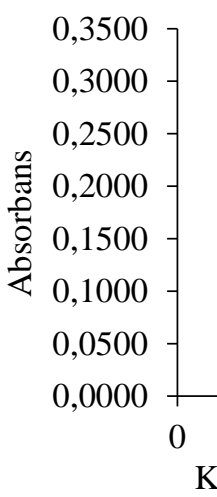 } & \multirow{8}{*}{$\begin{array}{r}\mathrm{y}=0.0053 \mathrm{x}-0 . \\
\mathrm{R}^{2}=0.8676\end{array}$} & \multirow{7}{*}{$\diamond$} \\
\hline & & \\
\hline & & \\
\hline & & \\
\hline & & \\
\hline & & \\
\hline & & \\
\hline & & $\neg$ \\
\hline & 20 & 60 \\
\hline & entrasi oksida g & $\mathrm{a}(\mu \mathrm{g} / \mathrm{mL})$ \\
\hline
\end{tabular}

Gambar 10. Hubungan Konsentrasi Asam Askorbat dengan serapan pada Panjang gelombang $700 \mathrm{~nm}$. 
Tabel 3. Hubungan konsentrasi asam askorbat dengan serapan pada panjang gelombang $700 \mathrm{~nm}$.

\begin{tabular}{ccc}
\hline Sampel & $\begin{array}{c}\text { Konsentrasi } \\
(\mu \mathrm{g} / \mathrm{mL})\end{array}$ & Absorbans \\
\hline & 10 & 0.075 \\
& 20 & 0.084 \\
Oksida grafena & 30 & 0.13 \\
& 40 & 0.171 \\
& 50 & 0.298 \\
\hline Blanko & - & 0.067 \\
\hline
\end{tabular}

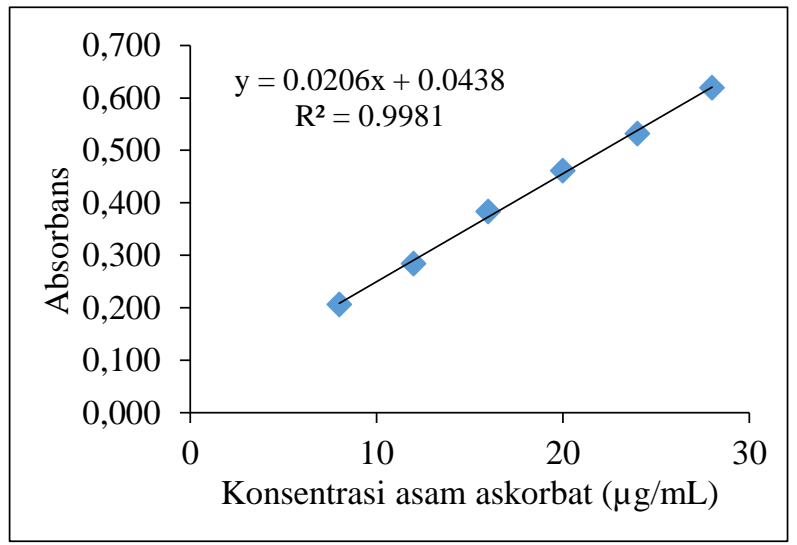

Gambar 11. Hubungan konsentrasi oksida grafena dengan serapan pada panjang gelombang $700 \mathrm{~nm}$.

\section{SIMPULAN}

Sintesis oksida grafena telah berhasil dilakukan menggunakan metode modifikasi Hummers dengan rendemen sebesar $1,85 \%$. Hasil sintesis yang didapatkan oksida grafena berbentuk bubuk halus warna hitam. Karakterisasi dengan PSA menunjukkan bahwa oksida grafena yang terbentuk memenuhi kriteria sebagai partikel nano yaitu $33,79 \mathrm{~nm}$. Hasil karakterisasi dengan alat spektrofotometer UV-Vis menunjukan adanya puncak serapan oksida grafena pada $232 \mathrm{~nm}$. Karakterisasi dengan FTIR adanya gugus fungsi C$\mathrm{H}, \mathrm{C}-\mathrm{O}, \mathrm{C}=\mathrm{O}$ dan $\mathrm{O}-\mathrm{H}$ yang merupakan gugus fungsi yang ada dalam oksida grafena. Karakterisasi dengan XRD menunjukan bahwa oksida grafena memiliki sudut $23,5^{\circ}$ dan kristalinitas sebesar 6,85\% yang berarti sebagian besar berbentuk amorf. Pengujian aktivitas antibakteri dengan metoda difusi sumur menunjukkan daya hambat bakteri dengan terbentuknya zona bening namun tergolong berdaya hambat rendah. Untuk kemampuan sebagai antioksidan oksida grafena hanya memiliki kemampuan sebesar 50\% lebih rendah dibandingkan dengan standar.

\section{UCAPAN TERIMA KASIH}

Penulis mengucapkan terima kasih kepada Departemen kimia, FMIPA, IPB, dan Laboratorium Kimia Terpadu, IPB atas bantuanya dalam memberikan fasilitas peminjaman laboratorium dan support bahan-bahan pada penelitain ini.

\section{REFERENSI}

[1] C. Lee, X. Wei, J. Kysar, and J. Hone, "Measurement of the elastic properties and intrinsic strength of monolayer graphene", Science, vol. 321, no. 5887, pp. 385-388, 2008.

[2] K.P. Loh, Q. Bao, G. Eda, and M. Chhowalla, "Graphene oxide as a chemically tunable platform for optical applications", Nature Chemistry, vol. 2, no. 12, pp. 1015-1024, 2010.

[3] J. McDonald-Wharry, M. Manley-Harris, and K. Pickering, "Carbonisation of biomass derived chars and the thermal reduction of a graphene oxide sample studied using Raman spectroscopy", Carbon, vol. 59, pp. 383-405, 2013.

[4] S.S. Shams, L.S. Zhang, R. Hu, R. Zhang, and J. Zhu, "Synthesis of graphene from biomass: A green chemistry approach", Materials Letters, vol. 161, pp. 476-479, 2015.

[5] A. Sjahriza, Z.A. Mas'ud, and K. Sutirah, "Mechanical and barrier properties of PVPcarbon dot nanocomposite film", Jurnal Kimia Terapan Indonesia, vol. 20, no. 2, pp. 49-56, 2018.

[6] K. Gerani, H.R. Mortaheb, and B. Mokhtarani, "Preparation and characterization of sulfonated polyether sulfone composite ionexchange membranes filled by graphene oxide Nano sheets", Conference: 12th International Conference on Membrane science \& technology, 2015.

[7] J. Chen, B. Yao, C. Li, and G. Shi, "An improved hummers metode foe eco-friendly synthesis of grafena oxide", Journal Carbon, vol. 64, pp. 225-229, 2013.

[8] L.Y. Ersan, T. Oscan, A.A. Bayizit, and S. Sahin, "The antioxidative capacity of kefir produced from goat milk. international", Journal of Chemical Engineering and Applications, vol. 7, no. 1, pp. 22-26, 2016.

[9] T. Chen, B. Zeng, J.L. Liu, J.H. Dong, X.Q. Liu, Z. Wu, and Z.M. Li, "High through put exfoliation of graphene oxide from expanded graphite with assistance of strong oxidant in modified Hummers method", Journal of 
Physics: Conference Series, vol. 188, no. 1, 2009.

[10] M.L. Bhaisare, A. Talib, M.S. Khan, S. Pandey, and H.F. Wu, "Synthesis of fluorescent carbon dots via microwave carbonization of citric acid in presence of tetraoctylammonium ion, and their application to cellular bioimaging", Microchimia Acta, vol. 182, pp. 2173-2181, 2015.

[11] J.D. Mangadlao, C.M. Santos, M.J.L. Felipe, A.C.C. Leon, D.F. Rodrigues, and R.C. Advincula, "On the antibacterial machanism of graphene oxide (GO) langmuir blodget films", Journal Chemistry, vol. 51, no. 2, pp. 2886-2889, 2015.

[12] V.H. Pham, H.D. Pham, T.T. Dang, S.H. Hur, E.J. Kim, et al., "Chemical reduction of an aqueous suspension of graphene oxide by nascent hydrogen", Journal of Materials Chemistry, vol. 22, no. 21, 2012,

[13] G. Supriyanto, N.K. Rukhman, A.K. Nisa, M. Jannatin, B. Piere, Abdullah, M.Z. Fahmi, and H.S. Kusuma, "Graphene oxide from Indonesia biomass: Synthesis and characterization", Bio Resources, vol. 13, no. 13, pp. 4832-4840, 2018.

[14] S. Guo, G. Zhang, Y. Guo, and J.C. Yu, "Graphene oxide- $\mathrm{Fe}_{2} \mathrm{O}_{3}$ hybrid material as highly efficient heterogeneous catalyst for degradation of organic contaminants", Journal Carbon, vol. 60, no. 39, pp. 437-444, 2013.
[15] G. Surekha, K.V. Krishnaiah, N. Ravi, and P. Suvarna, "FTIR, Raman and XRD analysis of graphene oxide films prepared by modified Hummers method", Journal of Physics: Conference Series. Vol. 1495, pp. 1-6, 2020.

[16] R.R. Ghanim, M.A. Hussien, and M.R. Muhammad, "Antibacterial activity and morphological characterization of synthesis graphene oxide nanosheets by simplified hummerss method", Journal Biotech Research Asia, vol. 15, no. 3, pp. 627-633, 2018.

[17] D.R. Dreyer, S. Park, and C.W. Bielawski, "The chemistry of graphene oxide", Chemical Society, vol. 39, no. 1, pp. 228-240, 2010.

[18] S. Liu, T.H. Zeng, M. Hofmann, E. Burcombe, J. Wei, R. Jiang, J. Kong, and Y. Chen, "Antibacterial activity of graphite, graphite oxide, graphene oxide, and reduced graphene oxide: membrane and oxidative stress", $A C S$ Nano, vol. 5, no, 9, pp. 6971-6980, 2011.

[19] Y. Qiu, Z. Wang, C.E. Alisa, S. Owen, I. Kulaots, et al., "Antioxidant chemistry of graphene-based materials and its role in oxidation protection technology", Nanoscale, vol. 6, no. 1, pp. 1744-11755, 2014.

[20] H. Saleem , M. Haneef , and H.Y. Abbasi, "Synthesis route of reduced graphene oxide via thermal reduction of chemically exfoliated graphene oxide", Materials Chemistry and Physics, vol. 204, pp. 1-7, 2018. 